\title{
Analysis of Life Insurance Market in Northwest Ethnic Regions in China
}

\author{
Jianshen Zhang ${ }^{1}$ \\ ${ }^{1}$ School of Economics, Northwest University for Nationalities, Lanzhou, China \\ Correspondence: Jianshen Zhang, Associate Professor, School of Economics, Northwest University for Nationalities, \\ Lanzhou, China. E-mail: jingjizjsh@163.com \\ Received: July 4, 2014 \\ Accepted: July 22, 2014 \\ Online Published: August 11, 2014 \\ doi:10.5430/jms.v5n3p45 \\ URL: http://dx.doi.org/10.5430/jms.v5n3p45
}

This work was supported by the Fundamental Research Funds for the Central Universities of Northwest University for Nationalities (Grant No.31920130096).

\begin{abstract}
The expansion of the life insurance market in northwest ethnic regions is not only an essential part to promote steady and rapid development of China's insurance industry and build the harmonious society, but also the cornerstone of all nationalities' progress and prosperity. In recent years, the economic growth of northwest ethnic regions provides a rich potential for the life insurance market and promote the further development of the life insurance industry at the same time. In this paper, the author uses the depth of life insurance and life insurance density to analyze the life insurance market status of northwest ethnic regions with selected four provinces. The conclusions show that the life insurance market in northwest ethnic regions is still with great market potential.
\end{abstract}

Keywords: northwest ethnic regions, life insurance market, the depth of the life insurance, the density of the life insurance

\section{Introduction}

Although life insurance serves as an approach of individuals' risk management against death risk, most of the life insurance products are saving instruments. Life insurance belongs to the contractual savings instruments. They are characterized by regular and long-term cash flows as well as illiquidity. As such, contractual savings is important source of finance for private and government long-term investment projects. In china, life insurance demand has experienced a rapid growth over the last few decades, both as provider of financial services to consumers and as a major investor in the capital market. China's life insurance market is characterized by its small size, a limited variety of insurance products, relatively high costs, lacking of a sound legal environment, particularly in the area of enforcement. However, the growth of life insurance did not match on the same level, not only among developed regions and coastal regions, but also there is a difference between western regions. The large disparity across different regions in the use of life insurance raises questions about what causes this variation and thus what determines life insurance consumption. A number of authors have proposed a variety of different socio-economic and institutional factors as possible determinants of life insurance consumption.

With the implementation of the Western Development policy, the economy of Northwest Ethnic Regions increase rapidly, residents' incomes raise constantly, more and more people access to education and risk conditions change gradually that provide a forceful guarantee for the development of the life insurance market. According to the 1-percent national population sample census in 2005, the 55 ethnic minorities had 123.33 million people, making up 9.44 percent of the national total. Of them, 3.6 millions ethnic minorities have located in Northwest regions. This paper contribution resides in a new effort to understand the life insurance market within a sample of four northwest ethnic regions (Ningxia, Gansu, Qinghai and Xingjiang) for the period 2005 - 2010. the author believe that the analysis of Life Insurance Market in Northwest Ethnic Regions will play a significant role in sustained and stable development of the insurance market in this region even in that of China. The paper is organized as follows. Section 2 presents the current status and existing problems of the life insurance market in Northwest Ethnic Regions. The analysis of the life insurance market potential in Northwest Ethnic Regions is given in section 3. Section 4 will be the strategies for promoting the development of Northwest Ethnic Regions life insurance market. The last section is the conclusion and implications. 


\section{The Status and Problems of the Life Insurance Market in Northwest Ethnic Regions}

In recent years, the economy of Northwest Ethnic Regions improves constantly and life insurance market also gained significant development, especially in the aspects of market subjects, business types, etc. But there are also some problems.

\subsection{The Situation of Life Insurance Market in Northwest Ethnic Regions}

\subsubsection{Continuous Expansion of Market}

The main indicators of the insurance industry market size are density and depth of insurance. Insurance density is the ratio of total annual premium of a country or a region and total population, which reflects the popularity of insurance industry and the demand for insurance. Insurance depth is the ratio of total annual premium and annual GDP of a country or a region, which reflects the status and relative development level of the insurance industry in the national economy. In recent years, driven by the economy, these two indicators of Northwest Ethnic Regions' life insurance industry show the rising trend overall. (Table 1)

Table 1. 2005-2010 the density values, depth values and relevant data of northwest ethnic regions life insurance

\begin{tabular}{ccccccccc}
\hline & & & & & & \multicolumn{2}{c}{ Unit: 100 million Yuan, 10 thou } \\
Year & $\begin{array}{c}\text { Life } \\
\text { insurance } \\
\text { premium }\end{array}$ & $\begin{array}{c}\text { Total } \\
\text { population }\end{array}$ & $\begin{array}{c}\text { Value(yuan/ } \\
\text { persen) }\end{array}$ & $\begin{array}{c}\text { Growth } \\
\text { rate }\end{array}$ & GDP & & Value (\%) & $\begin{array}{c}\text { Growth } \\
\text { rate }\end{array}$ \\
\hline 2005 & 84.48 & 5743 & 147.1 & & 5694.1 & 1.48 & \\
\hline 2006 & 100.74 & 5808 & 173.4 & 17.91 & 6696.36 & 1.50 & 1.35 \\
\hline 2007 & 118.87 & 5874 & 202.37 & 16.67 & 7942.02 & 1.50 & 0 \\
\hline 2008 & 197.82 & 5931 & 333.54 & 64.82 & 9572.57 & 2.07 & 38 \\
\hline 2009 & 200.1 & 5976 & 334.84 & 0.39 & 10089.19 & 1.98 & -4.35 \\
\hline 2010 & 239.61 & 5932 & 403.93 & 20.62 & 12532.1 & 1.91 & -3.54 \\
\hline
\end{tabular}

Note: According to the reference of the China Insurance Regulatory Commission website, the life insurance premium income is the sum of incomes of the four northwest ethnic provinces. According to the reference of CEInet statistics database, the total population and GDP is the sum of the four northwest ethnic provinces.

\subsubsection{The Increase of Insurance Companies}

Because of the inland location, there are mainly PICC, China Life, CPIC and Pingan Insurance companies which have been engaged in the life insurance industry for a long period. As a result, a relatively concentrated monopoly situation has formed. Since China joined the WTO in 2001 and proposed the Western Development policy, the number of life insurance companies in this area is increasing. Several large-scale insurance companies like NCI, Union Life, Taikang Life Insurance have been beginning its business. By the end of 2010, there have been 33 life insurance companies together.

\subsubsection{The Insurance Types Are Becoming Abundant}

In recent years, the life insurance types in Northwest Ethnic Regions' market break the traditional types gradually like term life insurance, whole-life insurance and endowment insurance, etc. In addition to investment-linked insurance, participating insurance, universal insurance and other investment types, there are also some local characteristic insurance, such as farmers and herdsmen supplementary medical insurance, altitude sickness insurance.

Farmers and herdsmen supplementary medical insurance is a serious illness business supplementary medical insurance which against the situation that the local cooperative medical system in rural and pastoral areas can't adequately meet the needs of farmers and herdsmen, which can improve the resilience of people. Altitude sickness insurance is specifically for tourists who go to Qinghai, Tibet and other places where accident or illness caused by acute high altitude hypoxia may happen. The insurance company will undertake the accidental injury death insurance and altitude sickness complication medical insurance, which is beneficial to promote the development of plateau tourism.

2.1.4 The Development of the Intermediary Market

With the expansion of the life insurance market, the insurance intermediary market in Northwest Ethnic Regions is 
also growing. Insurance intermediaries and practitioners gained rapid development. By the end of 2010, there have totaled 52 professional insurance agencies, 22 brokerage firms, 1 assessment company.

Table 2. 2010 the development of northwest ethnic regions professional insurance intermediary

\begin{tabular}{cccc}
\hline & Insurance agencies & Insurance brokerage firms & Insurance assessment companies \\
\hline Qinghai & 1 & & \\
\hline Gansu & 13 & 11 & \\
\hline Ningxia & 9 & 5 & 1 \\
\hline Xinjiang & 29 & 6 & 1 \\
\hline Sum & 52 & 22 & \\
\hline
\end{tabular}

Note: Data is derived from published data of the IIA

\subsection{Problems of Northwest Ethnic Regions'Life Insurance Market}

Northwest Ethnic Regions' life insurance market develops rapidly while still lagging behind the east. For example, in Xinjiang, which develops fastest in this region, by the end of 2010, there are 11 insurance companies, insurance density is 261.86 Yuan / person, the insurance depth is $1.8 \%$. While in eastern region, Shanghai for instance, there are 42 life insurance companies, insurance density and depth is 2982.97 Yuan per person and $4.07 \%$ in the same time. It fully reflects that the life insurance market in this region still develops slowly. The main reason is the lack of competition system. China Life, CPIC, Pingan and several other companies have been the core of the market in this region, the market share is concentrated. Meanwhile, the company's operations mainly focus on the capital cities or developed cities, so the market share is concentrated in this region, and without sufficient competition, companies also pretend to ignore the improvement and development of themselves. Imperfect institution, less standard behavior, low efficiency, such are also remain.

In the meantime, the minorities are nations with a long history, they have formed their unique psychological culture in their long-term production and social practices, especially there are deep-rooted religions and ethnic customs, these factors makes them accept new things comparatively slowly. Meanwhile the populations are with low qualities and they don't have risk consciousness and insurance consciousness. Conversely life insurance marketing is too professional and isn't aimed at exact groups, which causes the low status of the whole life insurance industry, so it can not play an essential role of developing.

\section{The Analysis of the Life Insurance Market Potential in Northwest Ethnic Regions}

\subsection{Risk Conditions Are Changing}

In Northwest Ethnic Regions, terrain is complex, climate is harsh and natural disasters happen frequently. The residents will face the natural disasters risks in a long-term, also with the increase of economy and the development of technology; they will pay close attention to property and life insurance. For example, in summer heavy rains or drought often happen in the loess plateau, and in winter snow storm in Qinghai Plateau is also very severe. These situations make people attach great importance to prevent natural disasters, so agricultural insurance is very popular. In addition to, the purchases of private car and transportation investment are increasing, so traffic accidents risks and other new risks increase. At last the problems in pension issues are more serious, which make people pay more and more attention to their own safety.

\subsection{Economy Is Increasing Continuously}

In recent years, GDP, per capita GDP and disposable income of urban and rural residents are on rise in Northwest Ethnic Regions, and the industrial structure has changed greatly. All these have laid foundations for the expansion of the life insurance market in the future.

\subsection{Social Conditions Have Improved}

With the continued economic development and the help of national policies, Northwest Ethnic Regions social security got a significant development. Security projects are more abundant and coverage is expanding. Qinghai, for example, by the end of 2009, participated in urban basic old-age insurance and workers, resident medical insurance were 71.34 million and 126.24 million, which make up $30.6 \%$ and $54.1 \%$ of the total urban population. The number of new rural cooperative medical service participators was 334.29 million, and the participation rate was $96.8 \%$.

But the development of Northwest Ethnic Regions is till in a low level compared to developed provinces, which calls for accelerating the development of the commercial life insurance protection, in order to meet the insurance demand, it can complete the deficiency of government and social security as well. And the rising level of urbanization 
provides a beneficial condition for the future development of the life insurance market.

\section{The Strategies for Promoting the Development of Northwest Ethnic Regions Life Insurance Market}

4.1 To Establish the Development Model Supported by the Government to Improve the Status of the Life Insurance Industry

Be restricted by geographical conditions, economic level and other factors, the life insurance industry is comparatively lagging behind the development of Northwest Ethnic Regions. There still exist some problems like product types are not so abundant and he number of target groups are small, low demand, high market monopoly, etc. In this case, government supporting is badly needed.

On the one hand, the government can reduce and exempt tax and provide low-interest or interest-free loans and other ways to lighten the finance burden of life insurance company capital load so as to mobilize investment initiative, to encourage more companies to develop business and establish branches in this region. On the other hand, the government could encourage companies to increase investment in new product development and to train professionals by incentives and security, to attract more high-quality insurance professionals to work in this region, to lay the foundation for market expansion.

\subsection{To Increase Market Subjects and Raise Competition Awareness}

The lack life insurance market subjects that lead to a situation that company have weak competition awareness in Northwest Ethnic Regions. Thus, increasing the number of subjects is extremely important in promoting the development of the life insurance market in this region.

On the one hand, life insurance companies should have a developing vision on the future development trend, and continuously expend competitive advantage by increasing research and investment of new insurance types, more training of marketing personnel and timely setting up branch offices, etc. On the other hand, the government could give financial and policy support, to attract social capital and foreign investment to establish a regional life insurance companies that offer life insurance business in Northwest Ethnic Regions, to increase the intensity of competition in the market.

\subsection{To Raise Residents' Awareness of Insurance and Improve the Life Insurance Marketing Model}

Northwest Ethnic Regions have a rich ethnic culture and different customs. Therefore, on the one hand, to raise residents' awareness of insurance, we can take good use of the various local ethnic customs and religions, organize acceptable performances. Besides, compile some life insurance publications which are easily read and understand to strengthen residents' consciousness of insurance participation. On the other hand, when promote the sale of the products, pay attention to the effect of ethnic religious influential figures, such as the Tibetan lama, Dalai Lama and Moslem mullah. And develop some marketing ways that suit local customs, including telemarketing, network marketing, etc.

In brief, with the improvement of regional economic conditions and (and the change of risk conditions and other elements, life insurance market in the Northwest Ethnic Regions has a bright prospect. It's believed that under the national and local governments' strong attention and the impetus of the effective policies the life insurance market will develop rapidly in the future.

Table 3. Northwest Ethnic Regions 2005-2010 GDP, per capita GDP and per capita disposable income of urban and rural residents data

100 million Yuan, Yuan

\begin{tabular}{|c|c|c|c|c|c|c|c|c|}
\hline \multirow[t]{2}{*}{ year } & \multicolumn{4}{|c|}{ Ningxia } & \multicolumn{4}{|c|}{ Xingjiang } \\
\hline & GDP & $\begin{array}{c}\text { per } \\
\text { capita } \\
\text { GDP }\end{array}$ & $\begin{array}{c}\text { per capita } \\
\text { disposable } \\
\text { income of } \\
\text { rural } \\
\text { residents }\end{array}$ & $\begin{array}{c}\text { per capita } \\
\text { disposable } \\
\text { income of } \\
\text { urban } \\
\text { residents }\end{array}$ & GDP & $\begin{array}{c}\text { per capita } \\
\text { GDP }\end{array}$ & $\begin{array}{l}\text { per capita } \\
\text { disposable } \\
\text { income of } \\
\text { rural residents }\end{array}$ & $\begin{array}{l}\text { per capita } \\
\text { disposable } \\
\text { income of } \\
\text { urban residents }\end{array}$ \\
\hline 2005 & 612.61 & 10349 & 2509 & 8094 & 2604.19 & 13108 & 2482 & 7990 \\
\hline 2006 & 725.9 & 12099 & 2760 & 9177 & 3045.26 & 15000 & 2737 & 8871 \\
\hline 2007 & 919.11 & 15142 & 3181 & 10859 & 3523.16 & 16999 & 3183 & 10313 \\
\hline 2008 & 1203.92 & 19609 & 3681 & 12932 & 4183.21 & 19797 & 3503 & 11432 \\
\hline 2009 & 1353.31 & 21777 & 4048 & 14025 & 4277.05 & 19942 & 3883 & 12258 \\
\hline
\end{tabular}




\begin{tabular}{ccccccccc}
\hline & \multicolumn{3}{c}{ Qinghai } & & \multicolumn{3}{c}{ Gansu } \\
\cline { 2 - 9 } & GDP & $\begin{array}{c}\text { per } \\
\text { capita } \\
\text { GDP }\end{array}$ & $\begin{array}{c}\text { per capita } \\
\text { disposable } \\
\text { income of } \\
\text { rural } \\
\text { residents }\end{array}$ & $\begin{array}{c}\text { per capita } \\
\text { disposable } \\
\text { income of } \\
\text { urban } \\
\text { residents }\end{array}$ & GDP & $\begin{array}{c}\text { per } \\
\text { capita } \\
\text { GDP }\end{array}$ & $\begin{array}{c}\text { per capita } \\
\text { disposable } \\
\text { income of } \\
\text { rural } \\
\text { residents }\end{array}$ & $\begin{array}{c}\text { per capita } \\
\text { disposable } \\
\text { income of urban } \\
\text { residents }\end{array}$ \\
\hline 2005 & 543.32 & 10045 & 2151 & 8058 & 1933.98 & 7477 & 1980 & 8087 \\
\hline 2006 & 648.5 & 11889 & 2358 & 9000 & 2276.7 & 8757 & 2134 & 8921 \\
\hline 2007 & 797.35 & 14506 & 2684 & 10276 & 20702.4 & 10346 & 2329 & 10012 \\
\hline 2008 & 1018.62 & 18421 & 3061 & 11640 & 3166.82 & 12110 & 2724 & 10969 \\
\hline 2009 & 1081.27 & 19454 & 3346 & 12692 & 3387.56 & 12872 & 2980 & 11930 \\
\hline
\end{tabular}

\section{Conclusion and Implications}

China is a big family with 56 ethnic groups. It must combine progress and prosperity of all nationalities to achieve the great rejuvenation of the Chinese nation. In this process, life insurance plays irreplaceable role in the prosperity of market economy and promotes social progress, safeguard people's life and stable social order. Further development of life insurance in northwest ethnic regions for the local economic development and works and life of the masses of ethnic minorities can provide not only the sustainable development of regional economy, but also promote the progress of minority nationalities, enhance national cohesion and maintain the long-term stability of the society. China's ethnic minorities accounted for large proportion of the total population, generally living in poor areas with relatively backward economies. Ethnic minorities in the case of natural disasters, illness or accident are very poor in economic bearing ability. Although there are many preferential policies and poverty alleviation funds provided by the State for the northwest ethnic regions, it is clear that the economic gap between northwest ethnic regions and the other regions has been widened in the last few years. This is not conducive to the coordinated development of the national economy and the common progress of all ethnic groups, but also can cause some other aspects of the contradictions. Thefore, it is necessary to expand the life insurance market in the northwest regions to enhance the self development ability for ethnic minorities and reduce the burden of national poverty alleviation.

\section{References}

Babbel, David F. (1979). Inflation's Impact on Life Insurance Costs: Brazilian Indexed and Non-Indexed Policies. Journal of Risk and Insurance, 46(4), 652-690. http://dx.doi.org/10.2307/252536

Browne, M. J., \& K. Kim. (1993). An International Analysis of Life Insurance Demand. Journal of Risk and Insurance, 60, 616-634. http://dx.doi.org/10.2307/253382

Chen, Renbao, Kie Ann Wong, \& Puay Fern Lau. (1998). Life Insurance Purchases in Singapore: Trends and Determinants. Asia Pacific Journal of Finance, 1, 87-105.

G. Hugh Russell, \& Kenneth Black, Jr. Atlanta. (1993). Human Behavior and Life Insurance. Georgia State University Business Press.

Hakansson, N. H. (1969). Optimal Investment and Consumption Strategies under Risk, and Uncertain Lifetime, and Insurance. International Economic Review, 10(3), 443-466. http://dx.doi.org/10.2307/2525655

Harold D. Skipper, Jr. (1987). Protectionism in the Provision of International Insurance Services. The Journal of Risk and Insurance, 54, 55-85. http://dx.doi.org/10.2307/252882

Kenneth Black, Jr., \& Harold D. Skipper, Jr. (2000). Life and Health Insurance. New Jersey: Prentice Hall.

Mantise, George, \& Richard N. Farmer. (1968). Demand for Life Insurance. Journal of Risk and Insurance, 35, 247-256. http://dx.doi.org/10.2307/250834

Neumann, Seev. (1969). Inflation and Saving Through Life Insurance. Journal of Risk and Insurance, 36(5), 567-582. http://dx.doi.org/10.2307/251163

Outreville, J. F. (1996). Life Insurance Markets in Developing Countries. Journal of Risk and Insurance, 63(2), 263-278. http://dx.doi.org/10.2307/253745 
Renbao Chen, Kie Ann Wong, \& Hong Chew Lee. (2001). Age, Period, and Cohort Effects on Life Insurance Purchases in the U.S.. The Journal of Risk and Insurance, 68, 303-327. http://dx.doi.org/10.2307/2678104

Rob, Gijsen. (1995). The Insurance Industry in China, Hong Kong. Asia Information Associates.

Sun, Qixiang, \& Sun, Jinyong. (1997). On the latent Demand Factors of China's Insurance Industry Growth. Reform.

Truett, Dale B., \& Lila J. Truett. (2011). The demand for Life Insurance in Mexico and The United States: A Comparative Study. Journal of Risk and Insurance, 57, 321-328. http://dx.doi.org/10.2307/253306

Vince E. Showers, \& Joyce A. Shotick. (1994). The Effects of Household Characteristics on Demand for Insurance: A Tobit Analysis. The Journal of Risk and Insurance, 61, 492-502. http://dx.doi.org/10.2307/253572

Xiao, Yunru. (2000). Insurance Demand and People's Attitudes to Risks. Nankai Economics Studies, 4, 121-132.

Yaari, M. (1965). Uncertain Lifetime, Life Insurance and the Theory of the Consumer. Review of Economics Studies, 32, 137-150. http://dx.doi.org/10.2307/2296058

Yat-ming Sin, \& Chi-fai Chan. (1987). The Consumer Profile of the Life Insurance Business in Hong Kong: An Exploratory Study. Department of Marketing and International Business, The University of Hong Kong. 